\title{
A M orphometric Study of Femur and Its Clinical Importance
}

\section{Ravi G.0 1, Shaik Hussain Saheb *2, Abraham Ratna Joseph N ${ }^{3}$.}

${ }^{1}$ Assistant Professor Department of Orthopedics, JJM M edical College, Davangere, Karnataka, India.

${ }^{* 2}$ Assistant Professor Department of Anatomy, JJM M edical College, Davangere, Karnataka, India.

${ }^{3}$ Assistant Professor, Avalon University School of M edicine Sta. Rosaweg, Willemstad, Curacao.

\section{ABSTRACT}

Background: The femur is the largest and strongest bone in the body and the structure of its proximal portion allows the leg to move in three dimensions relative to the torso, thus serving as a linchpin of human mobility. Moreover, age related and pediatric disorders at this skeletal site are common and confer strong risk factors for current and future disability. In Orthopaedic practice, operations on femur are the most common. Variations in hip morphology are also of critical interest to surgical planning where the ability to take hip morphology into account on a patient specific basis is crucial for success in choosing designs of implants and other structures used for hip replacements and augmentations of hip stability. The present study is focused on morphometric measurement of adult dry femur.

Objectives: The objectives of present study to find out the measurements of Neck shaft angle, Femoral Length and Neck Length of femur.

Materials and Methods: In present study have used 592 femurs from different colleges in south India. The following measurements were conducted Neck shaft angle, Femoral Length and Neck Length of femur.

Results: The results of present study are the length of femur was $447.1+28.94 \mathrm{~mm}$, right femur was $447.9+28.72 \mathrm{~mm}$ and left femur was $446.2+29.12 \mathrm{~mm}$, the Neck Length femur was $36.3+5.4 \mathrm{~mm}$, right femur was $36.4+5.2 \mathrm{~mm}$ and left femur was $36.1+5.6 \mathrm{~mm}$. the neck shaft angle of femur was $136.8^{\circ}$, right femur was $136.7^{0}$ and left femur was 136.9.

Conclusion: There is no significance difference between right and left femur measurements. The present study results are may helpful for orthopaedic, radiology and anthropological practice.

KEY WORDS: Femoral Length, Neck Length, Neck Shaft angle and Femur.

Address for correspondence: Shaik Hussain Saheb, Assistant Professor, Department of Anatomy, JJM M edical College, Davangere, Karnataka, India. M obile No.: +91-9242056660

E-Mail: anatomyshs@gmail.com

\begin{tabular}{|c|c|c|}
\hline \multicolumn{3}{|c|}{ Online Access and Article Informtaion } \\
\hline \multirow{2}{*}{$\begin{array}{c}\text { Quick Response code } \\
\text { Dol: } 10.16965 \text { /ijims.2016.135 }\end{array}$} & \multicolumn{2}{|c|}{$\begin{array}{l}\text { International Journal of Integrative Medical Sciences } \\
\qquad \text { www.imedsciences.com }\end{array}$} \\
\hline & $\begin{array}{l}\text { Received: 25-06-2016 } \\
\text { Reviewed: 27-06-2016 }\end{array}$ & $\begin{array}{l}\text { Accepted: 19-07-2016 } \\
\text { Published: 31-07-2016 }\end{array}$ \\
\hline Source of Funding: Self & & interest: None \\
\hline
\end{tabular}

\section{BACKGROUND}

The femur is the longest and strongest bone in the human body. It has shaft, proximal end and distal end. The shaft is slightly convex anteriorly [1]. Grossly mutilated skeletal remains are a big challenge for forensic pathologist and physical anthropologist in the identification of the deceased. The application of osteometry is most important in medico legal investigation for estimating the height which is part of achieving the goal of estimating age at the time of death, sex, race, ancestry, ethnicity, stature, body weight and body build. The details of individualizing characteristics that are amputation, fractures, ankylosis, deformities and bone pathologies and to some extent the cause of death if reflected in the skeletal remains are also essential in the identification 
of the individual. The objective is to enable the law enforcement agencies to achieve the ultimate goal of personal identification. Long bones that make up greatest proportion of stature, femur and tibia are more accurate than humerus and ulna. Intact long bones of upper and lower extremities have been used in derivation of regression equations for estimation of stature in different population groups. These bodies are sometimes presented to forensic anthropologists in different states of fragmentation, thereby making derived equations unstable. This has necessitated the need to assess the usefulness of measurement of fragments of long bones in estimation of stature [2]. It is also helpful for the clinicians in the treatment of proximal and distal femur fractures. Femoral neck fractures involve the narrow neck between the round head of the femur and the shaft [3].

The angle of the femur formed by the longitudinal axis of the neck and the longitudinal axis of the shaft of femur bone is termed as neck shaft or collodiaphysial angle. This angle varies with age, sex, race, dominant and non-dominant leg or development of femur. The neck shaft generally ranges from the angle of $115^{00}$ to $140^{\circ}$ at an average of $126^{\circ}$ in adults. The proximal femur acts as a brace, and its biomechanical properties depend on the width and length of the femoral neck. It also helps the limbs to swing clear of pelvis. Different aspects of clinical disease conditions and fracture, congenital anomalies and changes in osteoporosis as well as medico-legal cases can be understood by the study of femur bone. Femur bone has almost cylindrical shaft and a proximal rounded articular head projecting medially from its neck. The femoral neck is about $5 \mathrm{~cm}$ long and connects the head to shaft at about an angle of $135^{\circ}$. The mobility of hip joints is facilitated by the angle and it allows the obliquity of the femur within the thigh, which helps the knees to be adjacent and inferior to trunk. It enables to swing clear of the pelvis [4-6]. Numerous people are affected from fractures of the bone, especially in an elderly age. The lifetime risk of osteoporosis related fractures in the hip, spine and wrist is considered to be $30-40 \%$ in women and $13-20 \%$ in men[7]. As humans grow from childhood to adulthood, the neck shaft angle decreases significantly because of the changes in body portion and adaptation of hip joint to vertical posture[8]. Hip axis length, femoral neck axis length, neck shaft angle and femoral neck width collectively influence the risk of fracture especially in women apart from bone mineral density $[9,10]$. The present study is focused on find out the measurements of neck shaft angle, femoral Length and neck Length of femur, which is help in orthopaedic practice.

\section{MATERIALS AND METHODS}

In present study have used 250 femurs from different colleges in south India. The following measurements were measured Neck shaft angle, Femoral Length and Neck Length of femur. Instruments Used for this study are Sliding Calliper, Osteometric Board and measurements measured according to standard anthropometrical method[6,7].

\section{RESULTS}

The present study is conducted in different institutions in south India. The results of present study are the length of femur was $447.1+28.94$ $\mathrm{mm}$, right femur was $447.9+28.72 \mathrm{~mm}$ and left femur was $446.2+29.12 \mathrm{~mm}$, the Neck Length femur was $36.3+5.4 \mathrm{~mm}$, right femur was $36.4+5.2 \mathrm{~mm}$ and left femur was $36.1+5.6 \mathrm{~mm}$. the neck shaft angle of femur was $136.8^{\circ}$, right femur was $136.7^{\circ}$ and left femur was $136.9^{\circ}$.

Table 1: Showing the results of femoral length, Neck Length and Neck Shaft angle.

\begin{tabular}{|c|c|c|c|}
\hline \multicolumn{2}{|c|}{ Parameter } & Number & Mean \pm SD $(\mathrm{mm})$ \\
\hline \multirow{3}{*}{$\begin{array}{c}\text { Femoral } \\
\text { Length }\end{array}$} & Total & 592 & $447.1 \pm 28.94 \mathrm{~mm}$ \\
\cline { 2 - 4 } & Right & 281 & $447.9 \pm 28.72 \mathrm{~mm}$ \\
\cline { 2 - 4 } & Left & 311 & $446.2 \pm 29.12 \mathrm{~mm}$ \\
\hline \multirow{2}{*}{$\begin{array}{c}\text { Neck } \\
\text { length }\end{array}$} & Total & 592 & $36.3 \pm 5.4 \mathrm{~mm}$ \\
\cline { 2 - 4 } & Right & 281 & $36.4 \pm 5.2 \mathrm{~mm}$ \\
\cline { 2 - 4 } & Left & 311 & $36.1 \pm 5.6 \mathrm{~mm}$ \\
\hline \multirow{3}{*}{$\begin{array}{c}\text { Neck shaft } \\
\text { angle }\end{array}$} & Total & 592 & $136.8^{0} \pm 4.45^{0}$ \\
\cline { 2 - 4 } & Right & 281 & $136.9^{0} \pm 4.41^{0}$ \\
\cline { 2 - 4 } & Left & 311 & $136.7^{0} \pm 4.49^{0}$ \\
\hline
\end{tabular}

\section{DISCUSSION}

n present study, the mean neck-shaft angle of dry femur was observed $136.8^{\circ} \pm 4.45^{\circ}$, the right femur was $136.9^{\circ} \pm 4.41^{\circ}$ and left was $136.7^{0} \pm 4.49^{\circ}$, these readings which falls under 
the range $115^{\circ}$ to $140^{\circ}$ given by Moore et al [11]. The studies of Ali L et al [12], Ravichandran D [13] and Khan SM [14] are coherent with our findings. Present study shows no significant difference of neck shaft angle between right and left femur bone $(P>0.05)$. The right and left femur bones are measured with mean angles $136.9^{\circ} \pm 4.41^{\circ}$ and $136.7^{\circ} \pm 4.49^{\circ}$ respectively. These results are in correlation with study of Gujar et al[15]which has presented the mean value of $136.6^{\circ}$ of right and $136^{\circ}$ of left respectively. Another study reported the values lower than our study as the angle of 122.5 to the right and 125.6 to the left femur[16].

According to Reddy et al[17] a strong correlation has been established between the occurrence of thigh pain and inadequate fit and fixation of the implant. It has been noted that there is an increase in the clinical outcome score, which was directly proportional to the degree of implant bone fit. In using implants which have been designed for western contries, the chance of implant mismatch is much greater. This in turn may lead to increase in the rate of aseptic loosening, greater implant subsidence, and increased incidence of anterior thigh pain, more number of intraoperative complications and shorter lifespan of the implant[18].

The implant device and prosthesis designed for western skeleton are large in size, there angles, orientations and thread length also mismatch the femora. Implants that are designed by taking in to account anthropometric and bio mechanic data will help in designing patient specific implants thereby minimizing the complications [21]. Numerous studies have also shown that there is increase in the rate of intraoperative complication in the event of using mismatched implants especially over size implants[19].

In present study, the mean length of femur was $447.1 \pm 28.94 \mathrm{~mm}$, right femur was $447.9 \pm 28.72$ $\mathrm{mm}$ and left femur was $446.2 \pm 29.12 \mathrm{~mm}$. Our results are in agreement with Bhosale and Zambare[20]. In their study the mean length of left male femur was $45.23 \mathrm{~cm}$ that of left female was 42.04 , the mean length of right male femur was $45.08 \mathrm{~cm}$ that of right female was 41.64 $\mathrm{cm}$ [21]. Our measurements are similar to the study of Zuylan and M urshid in their study left femur length as $42.84 \mathrm{~cm}$, right femur length was $41.68 \mathrm{~cm}$. in study of S Dhivya[22] average length of femur was $41.66 \mathrm{~cm}$, right femur was $41.29 \mathrm{~cm}$ and left femur was $41.88 \mathrm{~cm}$. The difference in mean femoral length in between populations may possibly be a result of factors affecting bone morphology such as genetic constitution, diet, nutrition status, environment, and physical activity.

Our results in agreement with Pandya A M et al study[23], in this study mean value of maximum length was higher in male as compared to female. For right male bone calculated range was 379.99-523.63 and for right female bone it was 358.26-476.70, in same study right femur with maximum length more than $>476.70 \mathrm{~mm}$ can be correctly classified as a male and right femur with maximum length less than $<379.99$ $\mathrm{mm}$ can be correctly classified as a female, according to Pandya if the length is between $379.99 \mathrm{~mm}$ and $476.70 \mathrm{~mm}$, sexing was not possible[23]. The present study femur length is correlated with study of Rajeshwari S B[24] in this study the calculated range for right male was 379.88-523.33 $\mathrm{mm}$ and that for right female it was $358.16-476.80 \mathrm{~mm}$.

The mean femur neck length of present study was $36.3 \pm 5.4 \mathrm{~mm}$, the right femur neck length was $36.4 \pm 5.2 \mathrm{~mm}$ and the left femur neck length was $36.1 \pm 5.6 \mathrm{~mm}$, our results are in agreement with Ravichandran et al study, in their study the mean femur neck length was $31.88 \mathrm{~mm}$ [25]. Our results also in correlation with Siwach RC[26] study in his study the mean femur neck length was $37.2 \mathrm{~mm}$ and minimum effective neck length was $22.6 \mathrm{~mm}$. In study of SDhivya[22] the mean femur neck length was $3.09 \mathrm{~cm}$, right femur neck length was $2.98 \mathrm{~cm}$ and left femur neck length was $3.16 \mathrm{~cm}$. Our study is similar to that of De Sousa et al[27] in their study right femur neck length was $3.01 \mathrm{~cm}$, left femur neck length was $3.05 \mathrm{~cm}$.

The knowledge of the morphometric values of femoral segments is important in forensic, anatomic and archaeological cases in order to identify unknown bodies and stature[28,29]. It is also helpful for the clinician in the treatment of proximal and distal femoral fractures $[30,31,32]$. Therefore, the present study supplies the mean values of different morphometric measurements from the femur. As a result, these 
measurements may help to indicate the characteristic morphological features of femoral segments in south Indian population and also help the orthopaedic surgeon to place various implants in the reconstruction of femoral fragments.

\section{REFERENCES}

[1]. Susan Standring, Gray's Anatomy, The Anatomical basis of clinical practice, 40 edition, Elsevier Churchill Livingstone, London. 2008; 1360-13.

[2]. Bidmos M A. Estimation of stature using fragmentary femora in indigenous south Africans, Int J Legal Med.- 2008;122[4]:293-9.

[3]. Subtrochanteric femur fractures. Orthopaedia Main. In: Orthopaedia - Collaborative Orthopaedic Knowledgebase. Created Jan 27, 2008 17:18. Last modified Nov 22, 2009 20:14 ver.10.

[4]. Moore KL, Dalley AF, Agur AMR. Clinically Oriented Anatomy. USA: Lippincott Williams \& Wilkins; 2013.

[5]. Gujar S, Vikani S, Parmar J, Bondre KV. A Correlation Between Femoral Neck Shaft Angle to Femoral Neck Length. Int J Biomed \& Adv Res 2013; 4(5): 295-298.

[6]. Williams PL, Warwick R, Dyson M, Bannister LH. Gray's Anatomy. USA: Churchill Livingstone; 1989.

[7]. Tian PT, Chen Y, Leow WK, Hsu W, Howe TS, Png MA. Computing Neck Shaft Angle of Femur for X-Ray Fracture Detection. In: Petkov N, Westenberg, editors. Computer Analysis of Images and Patterns. CAIP 2003: Proceedings of 10 th International Conference; 2003 August 25-27; Groningen, The Netherlands. Berlin: Springer; 2003. 82-89.

[8]. Bulandra AM, Gielecki JS, Leciejewska I, Karaszewski P. Digital-Image Analysis of the Femoral Shaft/Neck Angle in Human Fetuses. Folia Morphol 2003; 62(4): 415-17.

[9]. Tuck SP, Rawlings DJ, Scane AC, Pande I, Summers GD, Woolf AD, Francis RM. Femoral Neck Shaft Angle in Men with Fragility Fractures. J Osteoporosis 2011; Article ID 903276. Available from: http:// dx.doi.org/ 10.4061/2011/903726.

[10]. Anusuya Shrestha, Nirju Ranjit, Rajani Shrestha. Neck Shaft Angle of Non-articulated Femur Bones among Adults in Nepal. MJSBH;2015;4(2):1-4.

[11]. Moore KL, Dalley AF, Agur AM RClinically Oriented Anatomy. USALippincott Williams \& Wilkins; 2013.

[12]. Ali L, Uddin S, Akhtar KM. 2003. Neck Shaft Angle of Femur in Paksitani Population. The Professional 2003; 10(1): 19-22.

[13]. Ravichandran D, Muthukumaravel N, Jaikumar R, Das H, Rajendran M. Proximal Femoral Geometry in Indians and its Clinical Applications. J Anat Soc Ind 2011; 60(1): 6-12.

[14]. Khan SM, Saheb SH. Study on Neck Shaft Angle and Femoral Length of South Indian Femurs. Int J Anat Res 2014; 2(4): 633-35.

[15]. Gujar S, Vikani S, Parmar J, Bondre KV. A Correlation Between Femoral Neck Shaft Angle to Femoral Neck Length. Int J Biomed \& Adv Res 2013; 4(5): 295-298.
[16]. Silva VJD, Oda JY, Santana DM G. Anatomical Aspects of the Proximal Femur of Adult Brazilians. Int J Morph 2003; 21(4): 303-308.

[17]. Reddy VS, Moorthy GV, Reddy SG. Do we need a special design of femoral component of total hip prosthesis in our patients? Indian J Orthop 1999;33:282-4.

[18]. M ishra AK, Chalise P, Singh RP, Shah RK. The proximal femur a second look at rational of implant design. Nepal Med Coll J 2009;11:278-80.

[19]. Leung K, Procter P, Robioneck B, Behrens K. Geometric mismatch of the gamma nail to the Chinese femur. Clin Orthop 1996:323:42-8.

[20]. Zuylan T, Murshid KA. An analysis of Anatolian human femur anthropometry. Turk J Med Sci 2002;32:231-35.

[21]. Bhosale RS, Zambare BR. Sex determination from femur using length of femur in Maharashtra. J Dent Med Sci 2013;3:01-3.

[22]. S Dhivya, V Nandhini. A Study of Certain Femoral Metrics in South Indian Population and its Clinical Importance International Journal of Scientific Study. 2015; 3(7):132-135.

[23]. Pandya A M, Singel T C, akbari V J, Dangar K P, Tank K C, Patel M P. Sexual dimorphism of maximum femoral Length. National journal of medical research. 2011;1(2).

[24]. Rajeshwari S. Bhosale, Dr. B. R. Zambare. Sex determination from femur using length of femur in Maharashtra. Journal of Dental and Medical Sciences. 2013;3(4):01-03.

[25]. Ravichandran D et al. Proximal femoral geometry in Indians and its clinical applications. J. Anat. Sco. India 2011;60(1):6-12.

[26].Siwach RC, Dahiya S. Anthropometric study of proximal femur geometry and its clinical apllication. Indian journal of Orthopaedics. 2003;37(4):247-51.

[27]. De Sousa EB, Fernandes RM, Mathias MB, Rodrigues M R, Ambram AJ, Babinski MA, et al. Morphometric study of the proximal femur extremity in Brazilians. Int J M orphol 2010;28:835-40.

[28]. Hussian SS, Mavishetter GF, Thomas ST, Prasanna LC, Muralidhar P. Occipitalization of Atlas: A case report. J Biomed Sci and Res 2010;2:73-5.

[29]. Hussain Saheb S, Mavishettar GF, Thomas ST, Prasanna LC. Incidence of metopic suture in adult south Indian skulls. J Biomed Sci Res 2010;2:223-6.

[30].Shaik HS, Shepur MP, Desai SD, Thomas ST, Maavishettar GF, Haseena S. Morphometric analysis of Infra orbital foramen position in south Indian skulls. Indian J. Innovations Dev. July 2012.

[31]. Shaik HS, Shepur Muralidhar P, Desai SD, Thomas ST, M aavishettar GF, Haseena S. Morphological and morphometric study of mental foramen south indian mandibles. Indian Journal of Medicine and Healthcare. 2012;1(3):64-66.

[32].M uralidhar P Shepur, Magi M, Nanjundappa B, Pavan P Havaldar, Premalatha Gogi, Shaik Hussain Saheb. Morphometric Analysis of Foramen Magnum. Int J Anat Res 2014; 2(1):249-55.

\section{How to cite this article: Ravi G.O, Shaik Hussain Saheb, Abraham Ratna Joseph N. A M orphometric Study of Femur and Its Clinical Importance. Int J Intg M ed Sci 2016;3(7):341- 344. DOI: 10.16965/ijims.2016.135}

